\title{
Halochromatium roseum sp. nov., a non-motile phototrophic gammaproteobacterium with gas vesicles, and emended description of the genus Halochromatium
}

\author{
Correspondence \\ Ch. Sasikala \\ r449@sify.com \\ or \\ sasi449@yahoo.ie
}

\author{
P. Anil Kumar, ${ }^{1}$ T. N. R. Srinivas, ${ }^{1}$ Ch. Sasikala ${ }^{1}$ and Ch. V. Ramana ${ }^{2}$ \\ ${ }^{1}$ Bacterial Discovery Laboratory, Centre for Environment, Institute of Science and Technology, \\ J. N. T. University, Kukatpally, Hyderabad 500 085, India \\ ${ }^{2}$ Department of Plant Sciences, School of Life Sciences, University of Hyderabad, PO Central \\ University, Hyderabad 500 046, India
}

\begin{abstract}
A rod-shaped, marine, phototrophic, purple sulfur bacterium containing gas vesicles was isolated from a marine solar saltern at Kakinada, India. Cells of strain JA134 ${ }^{\top}$ are Gram-negative, non-motile rods, with vesicular intracytoplasmic membranes, and the strain has an absolute requirement for $\mathrm{NaCl}$ for growth. Bacteriochlorophyll a and the carotenoid okenone are present as photosynthetic pigments. Phylogenetic analysis on the basis of 16S rRNA gene sequences showed that strain $\mathrm{JA} 134^{\top}$ clusters with members of the genus Halochromatium, but is distinctly separated from the species reported so far. The morphological and physiological differences of strain $\mathrm{JA} 134^{\top}$ from other Halochromatium species support the description of strain $\mathrm{JA} 134^{\top}$ $\left(=\right.$ ATCC BAA $\left.1363^{\top}=\mathrm{DSM} 18859^{\top}=\mathrm{JCM} 14151^{\top}\right)$ as the type strain of a novel species, Halochromatium roseum sp. nov.
\end{abstract}

The genus Halochromatium was established to separate the halophilic species of the genus Chromatium from their freshwater counterparts (Imhoff et al., 1998). At present, the genus Halochromatium contains two well-described species, Halochromatium salexigens (Imhoff et al., 1998) (originally described as Chromatium salexigens; Caumette et al., 1988) and Halochromatium glycolicum (Imhoff et al., 1998) (originally described as Chromatium glycolicum; Caumette et al., 1997). In the family Chromatiaceae, there are six genera that contain members that are reported to have gas vesicles, Thiocapsa (Thiocapsa rosea and Tca. pendens), Thiodictyon (Thiodictyon elegans and Tdc. bacillosum), Thiolamprovum (Thiolamprovum pedioforme), Thiopedia (Thiopedia rosea) and Lamprocystis (Lamprocystis roseopersicina and $L p c$. purpurea), which were isolated from freshwater habitats, while Lamprobacter (Lamprobacter modestohalophilus) was isolated from $\mathrm{H}_{2} \mathrm{~S}$-containing saline water bodies (Gorlenko \& Imhoff, 2005). However, neither the type strain of $L p b$. modestohalophilus, which represents the only species of this genus, nor its $16 \mathrm{~S}$ rRNA gene sequence is currently available, and no neotype strain has been designated (Gorlenko \& Imhoff, 2005). We

The GenBank/EMBL/DDBJ accession number for the $16 \mathrm{~S}$ rRNA gene sequence of strain $\mathrm{JA} 134^{\top}$ is $\mathrm{AM} 283535$.

A transmission electron micrograph of a cell of strain $\mathrm{JA} 134^{\top}$ and whole-cell and acetone-extract absorption spectra are available as supplementary material with the online version of this paper. observed the presence of gas vesicles in one of our isolates from a saltpan, the $16 \mathrm{~S}$ rRNA gene sequence of which clustered with those of members of the genus Halochromatium, but the phylogenetic distinctiveness and phenotypic variations observed with strain JA134 ${ }^{\mathrm{T}}$ indicate that it represents a novel species.

Strain JA134 ${ }^{\mathrm{T}}$ was isolated from photoautotrophic enrichments of a sample collected from a marine solar saltpan, which was in its initial stages of salt processing, at Kakinada, India $\left(16^{\circ} 54^{\prime} \mathrm{N} 82^{\circ} 13^{\prime} \mathrm{E}\right)$. The sample was a light-pinkish-coloured mat with subsurface black sooty sediment. Purification and polyphasic taxonomic studies were carried out as described earlier (Arunasri et al., 2005).

The genomic DNA was extracted and purified according to the method of Marmur (1961) and the G+C content was determined by HPLC (Mesbah et al., 1989). Cell material for $16 \mathrm{~S}$ rRNA gene sequencing was taken from 1-2 ml well-grown liquid culture. DNA was extracted and purified by using the Qiagen genomic DNA extraction kit. PCR amplification and 16S rRNA gene sequencing were performed as described previously (Imhoff et al., 1998). Recombinant Taq polymerase was used for PCR, which was started with the primers $5^{\prime}$-GTTTGATCCTGGCTCAG-3' and 5'-TACCTTGTTACGACTTCA-3' (respectively positions 11-27 and 1489-1506 according to the Escherichia coli 16S rRNA numbering of the International Union of Biochemistry). Sequences were obtained by cycle 


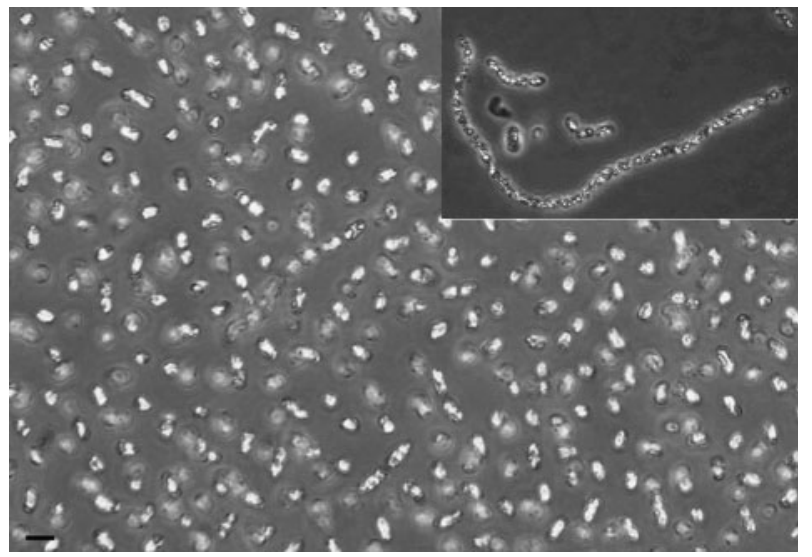

Fig. 1. Phase-contrast photomicrographs of cells of strain $\mathrm{JA} 134^{\top}$ showing gas vesicles and chain formation. Bar, $5 \mu \mathrm{m}$.

sequencing with the SequiTherm sequencing kit (Biozym) and the chain termination reaction (Sanger et al., 1977) using an automated laser fluorescence sequencer (Pharmacia). Sequences were aligned using the CLUSTAL $\mathrm{X}$ program (Thompson et al., 1997) and the alignment was corrected manually. The CLUSTAL $\mathrm{x}$ alignment file was used as the input file to the SEQBOOT program in the PHYLIP package (Felsenstein, 1993) and the output file of SEQBOOT was used as the input file for maximum-likelihood analysis with 100 datasets and five times jumbling. One single tree was generated using 100 trees generated during maximumlikelihood analysis using the CONSENSE program. The final dendrogram with evolutionary distances was constructed by taking the alignment .phy file as the infile and the consensus tree as intree in the maximum-likelihood program of the PHYLIP package (Felsenstein, 1993).
Samples were collected on 11 January 2006. The sample that yielded strain JA $134^{\mathrm{T}}$ had a $\mathrm{pH}$ of 6.8 , salinity of $2-3 \%$ and a temperature of about $30{ }^{\circ} \mathrm{C}$. Individual cells of strain JA134 ${ }^{\mathrm{T}}$ were rod-shaped, $2.0-3.0 \mu \mathrm{m}$ wide and 3.0-5.0 $\mu \mathrm{m}$ long, and non-motile, and they multiply by binary fission and occasionally form long chains (Fig. 1). Electron photomicrographs of ultrathin sections of the cells revealed a vesicular type of internal membrane structure and the presence of gas vesicles (see Supplementary Fig. S1 in IJSEM Online). Strain JA134 ${ }^{\mathrm{T}}$ was able to grow photolithoautotrophically [anaerobic, light from fluorescent lamp $\left(30 \mu \mathrm{E} \quad \mathrm{m}^{-2} \mathrm{~s}^{-1}\right), \quad \mathrm{Na}_{2} \mathrm{~S} .9 \mathrm{H}_{2} \mathrm{O} \quad(1 \mathrm{mM})$, $\mathrm{Na}_{2} \mathrm{~S}_{2} \mathrm{O}_{3} \cdot 5 \mathrm{H}_{2} \mathrm{O}(5 \mathrm{mM})$ and $\left.\mathrm{NaHCO}_{3}(0.1 \% \mathrm{w} / \mathrm{v})\right]$ and photolithoheterotrophically [anaerobic, light from fluorescent lamp $\left(30 \mu \mathrm{E} \mathrm{m} \mathrm{m}^{-2} \mathrm{~s}^{-1}\right), \quad \mathrm{Na}_{2} \mathrm{~S} .9 \mathrm{H}_{2} \mathrm{O}(1 \mathrm{mM})$, $\mathrm{NaHCO}_{3} \quad(0.1 \% \quad \mathrm{w} / \mathrm{v})$ and pyruvate $(0.3 \%$ w/v $\left.)\right]$. Photoorganotrophic and chemotrophic growth could not be demonstrated. In the presence of $1 \mathrm{mM} \mathrm{Na}_{2} \mathrm{~S} .9 \mathrm{H}_{2} \mathrm{O}$ and $0.1 \%(\mathrm{w} / \mathrm{v}) \mathrm{NaHCO}_{3}$, pyruvate, fumarate, succinate, malate, butanol, peptone, Casamino acids and glutamate were photoassimilated. Formate, acetate, propionate, butyrate, caproate, valerate, lactate, fructose, glucose, methanol, ethanol, propanol, glycerol, mannitol, glycolate, crotonate, ascorbic acid, 2-oxoglutarate and tartrate were not photoassimilated. Ammonium chloride and glutamine were utilized as nitrogen sources, while urea, nitrate, nitrite, glutamate and molecular nitrogen did not support growth. Sulfate assimilation was not observed. $\mathrm{Na}_{2} \mathrm{~S} .9 \mathrm{H}_{2} \mathrm{O}$ and $\mathrm{Na}_{2} \mathrm{~S}_{2} \mathrm{O}_{3} .5 \mathrm{H}_{2} \mathrm{O}$ were used as sulfur sources, whereas sulfate, sulfite, sulfur, thioglycolate and cysteine did not support growth. $\mathrm{NaCl}$ was required for growth of strain $\mathrm{JA} 134^{\mathrm{T}}$ at $1-3 \%(\mathrm{w} / \mathrm{v})$; the optimum $\mathrm{NaCl}$ concentration was $1.5-2.5 \%(w / v)$. Strain JA $134^{\mathrm{T}}$ grew at $\mathrm{pH} 7-8$ with optimum growth at $\mathrm{pH}$ 7.5. The temperature optimum for growth was $27^{\circ} \mathrm{C}$ (range $20-35^{\circ} \mathrm{C}$ ). The strain required

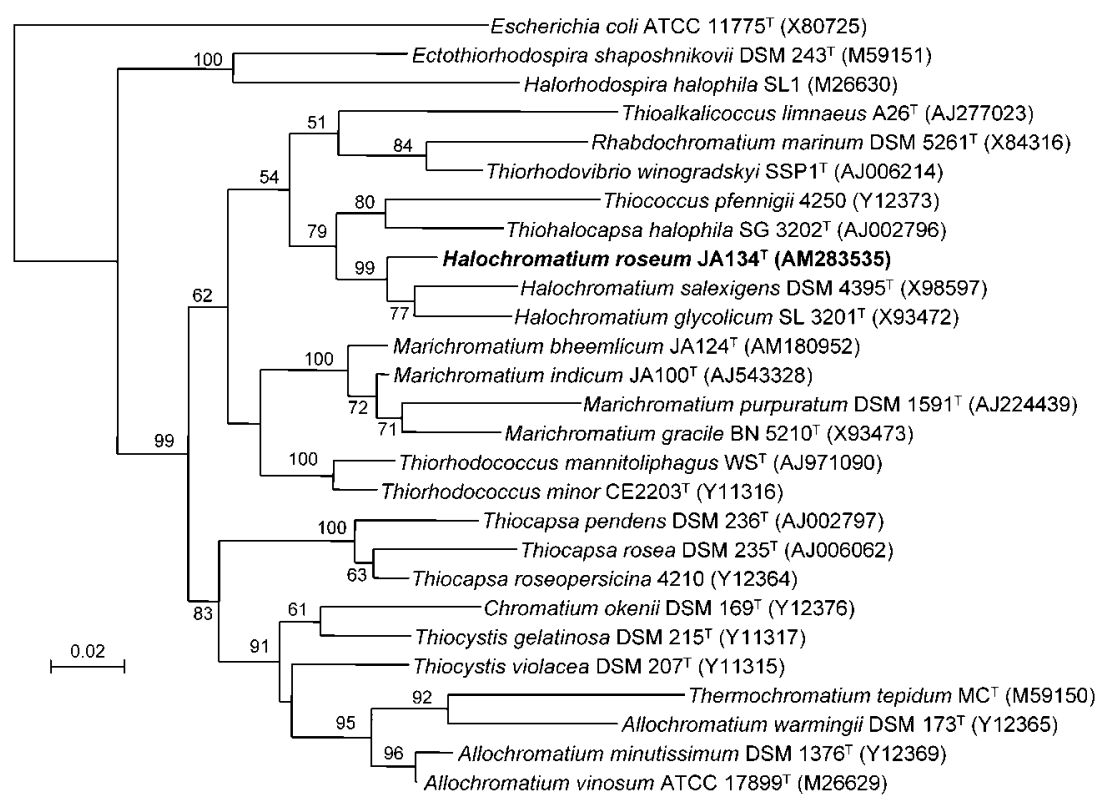

Fig. 2. Evolutionary-distance dendrogram depicting the phylogenetic relationships of strain $\mathrm{JA} 134^{\top}$ within the family Chromatiaceae as determined using 16S rRNA gene sequence analysis. Bar, 2 nucleotide substitutions per 100 nucleotides. 
vitamin $B_{12}$ as a growth factor. The colour of the photosynthetically grown cell suspension was purple-pink. The whole-cell absorption spectrum of strain $\mathrm{JA} 134^{\mathrm{T}}$ gave absorption maxima at $371,410,515,550,590,806,836$, 880 and $959 \mathrm{~nm}$, confirming the presence of bacteriochlorophyll $a$, and the absorption spectrum for pigments extracted with acetone gave absorption maxima at 462, 487 and $516 \mathrm{~nm}$, indicating the presence of carotenoids of the okenone group (Supplementary Fig. S2). The DNA base composition of strain $\mathrm{JA}_{13} 4^{\mathrm{T}}$ was $64 \mathrm{~mol} \% \mathrm{G}+\mathrm{C}$ (by HPLC). The phylogenetic relationships of strain JA134 $4^{\mathrm{T}}$ to other purple sulfur bacteria were examined by $16 \mathrm{~S}$ rRNA gene sequencing. The data obtained revealed that the new isolate branched separately but clustered with the type strains of species of the genus Halochromatium and was distinct from other genera of purple sulfur bacteria. The highest sequence similarities of strain $\mathrm{JA} 134^{\mathrm{T}}$ were found with the type strains of Hch. glycolicum (95.6\%) and Hch. salexigens $(95.4 \%)$ (Fig. 2). Apart from the 16S rRNA gene sequence dissimilarity, strain $\mathrm{JA}_{134^{\mathrm{T}}}$ showed clear phenotypic differences from other Halochromatium species (Table 1) that justify the description of a novel species, Halochromatium roseum sp. nov.

\section{Description of Halochromatium roseum sp. nov.}

Halochromatium roseum (ro'se.um. L. neut. adj. roseum rose-coloured, the colour of cell suspensions of the type strain).

Cells are rods, 2.0-3.0 $\mu \mathrm{m}$ wide and 3.0-5.0 $\mu \mathrm{m}$ long, and non-motile and cells divide by binary fission. Growth occurs under anaerobic conditions in the light (photolithoautotrophy/photoheterotrophy). Internal photosynthetic membranes are of the vesicular type. The colour of phototrophic cultures is purple-pink (rose). The in vivo absorption spectrum of intact cells in sucrose exhibits maxima at $371,410,515,550,590,806,836,880$ and $959 \mathrm{~nm}$. Bacteriochlorophyll $a$ and carotenoids of the okenone group are present. The type strain is mesophilic (optimum growth at $27^{\circ} \mathrm{C}$ ), with a $\mathrm{pH}$ optimum at 7.5 ,

Table 1. Differentiating characteristics of Halochromatium species and Lpb. modestohalophilus

Data for reference species were taken from Imhoff \& Caumette (2005) (Halochromatium species) and Gorlenko \& Imhoff (2005) (Lpb. modestohalophilus). +, Substrate utilized or present; -, substrate not utilized or absent; (+), weak growth; ND, not determined; NA, no data available. Sulfide and thiosulfate were utilized by all the strains. For all four taxa, organic substrate utilization was tested during photolithoautotrophic growth. Propionate, butyrate, glucose, fructose, crotonate and valerate were not utilized by any of the strains.

\begin{tabular}{|c|c|c|c|c|}
\hline Characteristic & Strain JA134 ${ }^{\mathrm{T}}$ & Hch. salexigens & Hch. glycolicum & Lpb. modestohalophilus \\
\hline Cell shape & Rod & Rod & Rod & Ovoid to rod \\
\hline Motility & - & + & + & + \\
\hline Cell size $(\mu \mathrm{m})$ & $2.0-3.0 \times 3.0-5.0$ & $2.0-2.5 \times 4.0-7.5$ & $0.8-1.0 \times 2.0-4.0$ & $2.0-2.5$ \\
\hline Gas vesicles & + & - & - & + \\
\hline Colour of cell suspension & Purple-pink & Pink, rose red & Pink, pinkish red & Purple-red \\
\hline Carotenoid group & Okenone & Spirilloxanthin & Spirilloxanthin & Okenone \\
\hline $\mathrm{G}+\mathrm{C}$ content of DNA $(\mathrm{mol} \%)$ & 64 & 64.6 & $66.1-66.5$ & $60-64$ \\
\hline Vitamin $B_{12}$ requirement & + & + & - & + \\
\hline Chemolithotrophic growth & - & + & + & + \\
\hline pH optimum (range) & $7.5(7-8)$ & $7.4-7.6(7.0-8.0)$ & $7.2-7.4(6.2-9.0)$ & $7.4-7.6$ \\
\hline Temperature optimum $\left({ }^{\circ} \mathrm{C}\right)$ & 27 & $20-30$ & $25-35$ & $23-27$ \\
\hline $\mathrm{NaCl}$ optimum (\%) (range) & $1.5-2.5(1-3)$ & $8-11(4-20)$ & $4-6(2-20)$ & $1-4(\leqslant 9)$ \\
\hline \multicolumn{5}{|l|}{ Photoassimilation of: } \\
\hline Formate & - & - & $(+)$ & - \\
\hline Acetate & - & + & $(+)$ & + \\
\hline Pyruvate & + & + & $(+)$ & + \\
\hline Lactate & - & - & - & + \\
\hline Fumarate & + & - & + & - \\
\hline Succinate & + & - & + & - \\
\hline Malate & + & - & - & - \\
\hline Ethanol & - & - & - & + \\
\hline Propanol & - & - & $\mathrm{NA}$ & + \\
\hline Glycerol & - & - & + & + \\
\hline Glycolate & - & - & + & NA \\
\hline Casamino acids & + & - & $(+)$ & NA \\
\hline \multicolumn{5}{|l|}{ Electron donors } \\
\hline Hydrogen & ND & + & + & + \\
\hline Sulfur & - & + & + & + \\
\hline
\end{tabular}


and requires $\mathrm{NaCl}(1.5-2.5 \%)$ for optimal growth. Photolithoautotrophy is the preferred mode of growth. Organic compounds such as pyruvate, fumarate, succinate, malate, glutamate, butanol, Casamino acids and peptone are photoassimilated in the presence of $1 \mathrm{mM} \mathrm{Na}_{2} \mathrm{~S} .9 \mathrm{H}_{2} \mathrm{O}$ and $0.1 \%(\mathrm{w} / \mathrm{v}) \mathrm{NaHCO}_{3}$. Chemotrophic growth can not be demonstrated. Vitamin $B_{12}$ is required as a growth factor. The DNA base composition of the type strain is $64 \mathrm{~mol} \% \mathrm{G}+\mathrm{C}$ (HPLC).

The type strain, $\mathrm{JA} 134^{\mathrm{T}}\left(=\mathrm{ATCC}\right.$ BAA- $1363^{\mathrm{T}}=\mathrm{DSM}$ $\left.18859^{\mathrm{T}}=\mathrm{JCM} 14151^{\mathrm{T}}\right)$, was isolated from a saltpan at Kakinada, India.

\section{Emended description of the genus Halochromatium Imhoff et al. 1998}

The description is as given previously (Imhoff et al., 1998; Imhoff \& Caumette, 2005) with the following modifications. Most species are without gas vesicles and grow at elevated salt concentrations, but some species possess gas vesicles and can grow only at lower salt concentrations (1$3 \% \mathrm{NaCl} \mathrm{w} / \mathrm{v})$.

\section{Acknowledgements}

Financial assistance received from the Department of Biotechnology and the Ministry of Earth Sciences, Government of India, is acknowledged. P.A.K. and T.N.R.S. acknowledge the CSIR, Government of India, for the award of SR fellowships.

\section{References}

Arunasri, K., Sasikala, Ch., Ramana, Ch. V., Süling, J. \& Imhoff, J. F. (2005). Marichromatium indicum sp. nov., a novel purple sulfur gammaproteobacterium from mangrove soil of Goa, India. Int J Syst Evol Microbiol 55, 673-679.

Caumette, P., Baulaique, R. \& Matheron, R. (1988). Characterization of Chromatium salexigens sp. nov., a halophilic Chromatiaceae isolated from Mediterranean salinas. Syst Appl Microbiol 10, 288-292.

Caumette, P., Imhoff, J. F., Süling, J. \& Matheron, R. (1997). Chromatium glycolicum sp. nov., a moderately halophilic purple sulfur bacterium that uses glycolate as substrate. Arch Microbiol 167, 11-18.

Felsenstein, J. (1993). PHYLIP (phylogeny inference package) version 3.5.1. Distributed by the author. Department of Genome Sciences, University of Washington, Seattle, USA.

Gorlenko, V. M. \& Imhoff, J. F. (2005). Genus V. Lamprobacter Gorlenko, Krasil'nikova, Kikina and Tatarinova $1988,220^{\mathrm{VP}}$. In Bergey's Manual of Systematic Bacteriology, 2nd edn, vol. 2, part B, pp. 16-18. Edited by D. J. Brenner, N. R. Krieg, J. T. Staley \& G. M. Garrity. New York: Springer.

Imhoff, J. F. \& Caumette, P. (2005). Genus III. Halochromatium Imhoff, Süling and Petri 1998b, 1139 VP. In Bergey's Manual of Systematic Bacteriology, 2nd edn, vol. 2, part B, pp. 14-15. Edited by D. J. Brenner, N. R. Krieg, J. T. Staley \& G. M. Garrity. New York: Springer.

Imhoff, J. F., Süling, J. \& Petri, R. (1998). Phylogenetic relationships among the Chromatiaceae, their taxonomic reclassification and description of the new genera Allochromatium, Halochromatium, Isochromatium, Marichromatium, Thiococcus, Thiohalocapsa and Thermochromatium. Int J Syst Bacteriol 48, 1129-1143.

Marmur, J. (1961). A procedure for the isolation of deoxyribonucleic acid from microorganisms. J Mol Biol 3, 208-218.

Mesbah, M., Premachandran, U. \& Whitman, W. B. (1989). Precise measurement of the $\mathrm{G}+\mathrm{C}$ content of deoxyribonucleic acid by highperformance liquid chromatography. Int J Syst Bacteriol 39, 159-167.

Sanger, F., Nicklen, S. \& Coulson, A. R. (1977). DNA sequencing with chain terminating inhibitors. Proc Natl Acad Sci U S A 74, 5463-5467.

Thompson, J. D., Gibson, T. J., Plewniak, F., Jeanmougin, F. \& Higgins, D. G. (1997). The CLUSTAL_X windows interface: flexible strategies for multiple sequence alignment aided by quality analysis tools. Nucleic Acids Res 25, 4876-4882. 